https://doi.org/10.15407/ujpe63.5.425

A. PANTHAWAN,${ }^{1,2}$ T. KUMPIKA, ${ }^{2}$ W. SROILA, ${ }^{2}$ E. KANTARAK,${ }^{2}$ W. THONGPAN,${ }^{2}$

P. POOSEEKHEAW ${ }^{2}$ R. SORNPHANPEE ${ }^{2}$ N. JUMRUS, ${ }^{2}$ P. SANMUANGMOON ${ }^{3}$

A. TUANTRANONT, ${ }^{4,5}$ P. SINGJAI ${ }^{2,5,6}$ W. THONGSUWAN ${ }^{2,5,6}$

${ }^{1}$ Graduate School Chiang Mai University (239, Huay Kaew Road, Muang, Chiang Mai 50200, Thailand)

2 Department of Physics and Materials Science, Faculty of Science, Chiang Mai University (239, Huay Kaew Road, Muang, Chiang Mai 50200, Thailand)

${ }^{3}$ Faculty of Science, Chiang Mai University (239, Huay Kaew Road, Muang, Chiang Mai 50200, Thailand)

4 Thailand Organic and Printed Electronics Innovation Center, National Electronics and Computer Technology Center, National Science and Technology Development Agency (Klong Luang, Pathumthani, 12120, Thailand)

${ }^{5}$ Center of Advanced Materials of Printed Electronics and Sensors, Materials Science Research Center, Faculty of Science, Chiang Mai University (Chiang Mai 50200, Thailand)

${ }^{6}$ Materials Science Research Center, Faculty of Science, Chiang Mai University (239, Huay Kaew Road, Muang, Chiang Mai 50200, Thailand; e-mail: wiradej.t@cmu.ac.th)

\title{
MORPHOLOGY AND PHASE TRANSFORMATION OF COPPER/ALUMINIUM OXIDE FILMS
}

\begin{abstract}
Copper aluminium oxide $\left(\mathrm{CuAlO}_{2}\right)$ was successfully prepared within the single-step sparking process at the atmospheric pressure. The as-deposited films were then annealed at 400, 900, 1000 , and $1100{ }^{\circ} \mathrm{C}$ in an oven. The results have shown that the annealing temperature has direct effect on the morphology, phase transformation, and optical properties. $\mathrm{CuAlO}_{2}$ in the delafossite phase was formed on the annealed films at temperatures higher than $900{ }^{\circ} \mathrm{C}$. Furthermore, the energy band gaps of the annealed films were linearly increased from 3.3 to $3.8 \mathrm{eV}$ with increasing the annealing temperature from 400 to $1100^{\circ} \mathrm{C}$ due to a reduction of the oxygen deficit of films at high annealing temperatures.

Ke ywords: sparking process, $\mathrm{CuAlO}_{2}$, annealing, phase transformation.
\end{abstract}

\section{Introduction}

Transparent conducting oxide is one of the most advanced topics for a wide range of equipment applications and for credible wide band gap oxide semiconductors. Transparent oxides with $p$-type and $n$ type are severely limited for the development of $p-n$ junction based devices such as transistors, transparent diodes, light emitting diodes (LEDs), and various other optoelectronic devices [1-6]. In recent years, semiconducting delafossite oxides such as copper aluminium oxide $\left(\mathrm{CuAlO}_{2}\right)$ have attracted much inter-

(c) A. PANTHAWAN, T. KUMPIKA, W. SROILA,

E. KANTARAK, W. THONGPAN, P. POOSEEKHEAW,

R. SORNPHANPEE, N. JUMRUS,

P. SANMUANGMOON, A. TUANTRANONT,

P. SINGJAI, W. THONGSUWAN, 2018 est as $p$-type semiconductors due to their optical and electrical properties [8]. $\mathrm{CuAlO}_{2}$ has a direct band gap in the interval $3.5-4.0 \mathrm{eV}$, while the indirect band gap is $2.0 \mathrm{eV}$ [9]. Thus, $\mathrm{CuAlO}_{2}$ can be used as amassing in a dye-sensitized solar cell [5]. Several methods have been used for the synthesis of $\mathrm{CuAlO}_{2}$ films such as the sputtering [10-11], sol-gel [12], solution [13], pulsed laser deposition [14], chemical vapour deposition [15], and sparking [16] ones.

In this work, we prepare $\mathrm{CuAlO}_{2}$ films on the quartz substrate using a single step of the sparking method without vacuum system [16]. The as-deposited films were annealed at 400,900, 1000, and $1100{ }^{\circ} \mathrm{C}$ for $1 \mathrm{~h}$. to improve their crystallinity. The morphology and structural and optical properties of the films were characterized by scanning electromicroscopy (SEM), energy dispersive x-ray (EDX), X- 


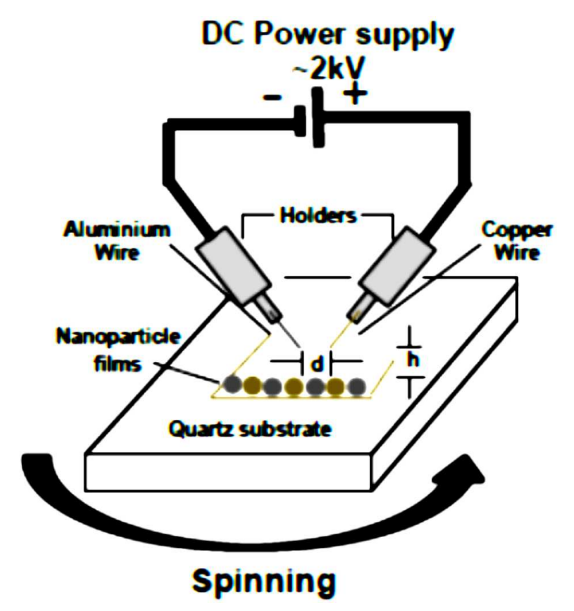

Fig. 1. Schematic diagram of a sparking apparatus
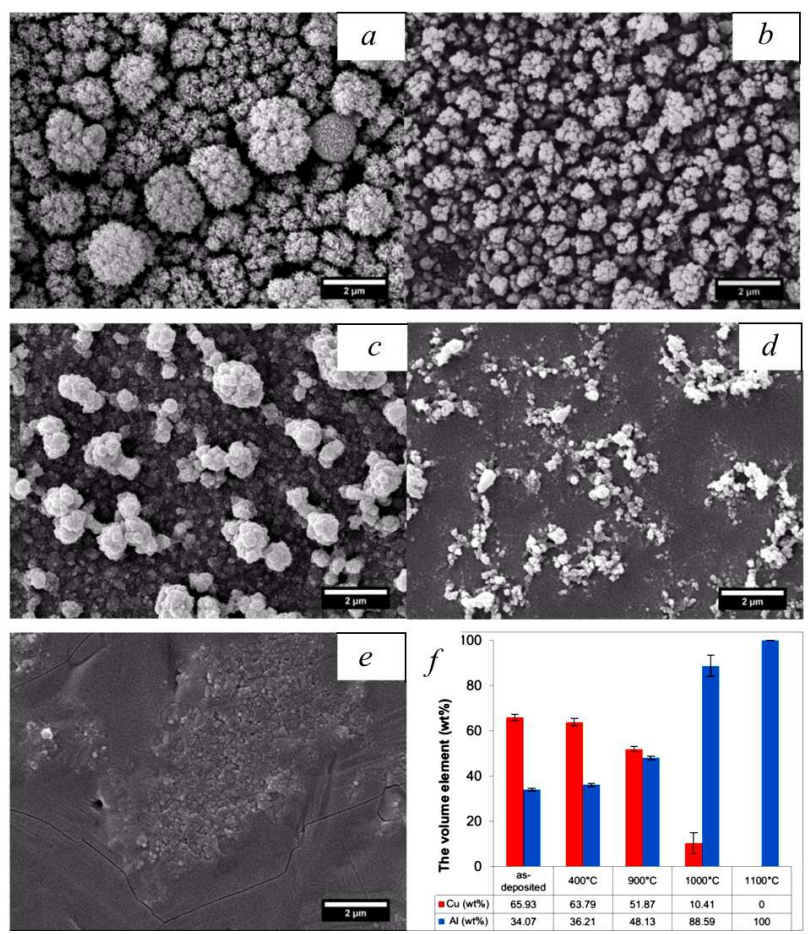

Fig. 2. SEM images of as-deposited films $(a)$, the annealed films at $400(b), 900(c), 1000(d)$, and $1100{ }^{\circ} \mathrm{C}(e)$ and their $\operatorname{EDS}(f)$

ray diffraction (XRD), and UV/vis spectroscopy. Furthermore, the phase composition of the film surfaces was characterized using X-ray photoelectron spectroscopy (XPS). The effect of the annealing temperature on their properties will be described and discussed in what follows.

\section{Experimental Details}

The experiment was carried out using the sparking off $\mathrm{Al}(0.25 \mathrm{~mm}, 99.9 \%$, SIGMA-ALDRICH Chemistry, USA) and $\mathrm{Cu}(0.58 \mathrm{~mm}, 99.9 \%$, Advent Research Material Ltd, UK) tips with the high DC voltage of $2 \mathrm{kV}$ under atmospheric pressure, as shown in Fig. 1. The tips were placed at the 1-mm spacing, while the tips were also placed above the quartz substrate at a distance of $1 \mathrm{~mm}$. In the sparking process for $1 \mathrm{~h}$ and the deposition rate of $125 \mathrm{~nm} / \mathrm{min}$, small particles of $\mathrm{Cu}$ and $\mathrm{Al}$, which are generated by the bombardment by electrons and ions at the two tip surfaces, were deposited on the substrate to form the films. The as-deposited films were then annealed in a furnace at 400, 900, 1000, and $1100{ }^{\circ} \mathrm{C}$ for $1 \mathrm{~h}$. The film morphology was characterized by SEM (JEOL JSM300), the film components were determined by using EDX. The crystal structures and the phase composition of the films were investigated by XRD (Rigagu; $\mathrm{CuK}_{\alpha}$ radiation with $\lambda=0.1541862 \mathrm{~nm}$ operating at $40 \mathrm{kV}$, $30 \mathrm{~mA}$ ) and XPS (AXIS ULTRADLD, Kratos analytical, Manchester, UK). Moreover, the optical properties including the energy gap of the films can be characterized by $\mathrm{UV} /$ vis spectroscopy (Hitachi $\mathrm{U}-4100)$.

\section{Results and Discussion}

Fig. 2, $a-e$ shows SEM images of the as-deposited and annealed films at 400, 900, 1000 , and $1100{ }^{\circ} \mathrm{C}$ for $1 \mathrm{~h}$, respectively. From the figures, it is clearly seen that the as-deposited films (Fig. 2, a) have a high porosity. According to the high surface energy of nanoparticles, $\mathrm{Cu} / \mathrm{Al}$ nanoclusters were then agglomerated to decrease their surface energy [17]. The surface roughness and the particle sizes of the films were decreased with increasing the annealing temperature (see Fig. 2, $b-e$ ). When the films are annealed at 900 and $1000^{\circ} \mathrm{C}$, it is seen that some of $\mathrm{Al}$ particles are melted, because the melting temperature of $\mathrm{Al}$ is lower than $900{ }^{\circ} \mathrm{C}[18]$. When the films are annealed at $1100{ }^{\circ} \mathrm{C}, \mathrm{Cu} / \mathrm{Al}$ particles are totally melted since the temperature was higher than the melting point of copper [18]. The weight $\%$ of $\mathrm{Cu} / \mathrm{Al}$ on the films is shown in Fig. 2, $f$. It is found that the weight $\%$ of $\mathrm{Cu}$ decreases, while the weight $\%$ of $\mathrm{Al}$ increases, as the annealing temperature increases. This is because the melting temperature of $\mathrm{Al}$ lower than that of $\mathrm{Cu}$ leads

ISSN 2071-0194. Ukr. J. Phys. 2018. Vol. 63, No. 5 
to the coverage on $\mathrm{Cu}$ particles at the high annealing temperature.

Figure 3 shows XRD patterns of the as-deposited films and films annealed at various temperatures for $1 \mathrm{~h}$. From the figure, no significant peak is observed at the annealing temperature lower $400{ }^{\circ} \mathrm{C}$. At the annealing temperature of $900{ }^{\circ} \mathrm{C}$, the peaks were observed at $35.6^{\circ}$ and $38.9^{\circ}$, which correspond to $\mathrm{CuO}$ [19], while the peak at $36.9^{\circ}$ is related to $\mathrm{CuAl}_{2} \mathrm{O}_{4}$ [20]. After the annealing at more that $900{ }^{\circ} \mathrm{C}$, the peaks are clearly observed at $21.6^{\circ}$ and $35.8^{\circ}$, which confirms that the film is $\mathrm{CuAlO}_{2}$ [21].

The $\mathrm{CuAlO}_{2}$ film annealed at $1100{ }^{\circ} \mathrm{C}$ were studied by XPS spectra, as shown in Fig. 4. From the figure, we see that all strong peaks of $\mathrm{Cu}, \mathrm{Al}$, and $\mathrm{O}$ correspond to the state of $\mathrm{CuAlO}_{2}$. That is, the main peaks of $\mathrm{Cu} 2 p$ were observed at the binding energies of $933.2 \mathrm{eV}$ and $952.9 \mathrm{eV}$, which correspond to $\mathrm{Cu} 2 p_{3 / 2}$ and the spin orbital $\mathrm{Cu} 2 p_{1 / 2}$ (see Fig. 4, a) [22]. However, the states of $\mathrm{CuO}$ are remained at $935.0 \mathrm{eV}$ and $953.9 \mathrm{eV}$, while the states of $\mathrm{CuAl}_{2} \mathrm{O}_{4}$ are also remained at $934.6 \mathrm{eV}$ and $952.6 \mathrm{eV}[24]$. Figure $4, b$ shows the $\mathrm{Al} 2 p\left(\mathrm{Al}^{3+}\right)$ peak at $74.5 \mathrm{eV}$, which corresponds to $\mathrm{Al}^{+3}-\mathrm{O}^{-2}$ bonds of $\mathrm{CuAlO}_{2}$ [22], whereas the peak at $74.7 \mathrm{eV}$ corresponds to $\mathrm{CuAl}_{2} \mathrm{O}_{4}$ [25]. Figure 4, $c$ shows the main peak at $532.6 \mathrm{eV}$ of $\mathrm{O} 1 \mathrm{~s}$, which corresponds to $\mathrm{O}^{2-}$ $\mathrm{Cu}^{+1}$ [22]. The binding energy at $531.4 \mathrm{eV}$ corresponds to $\mathrm{O}^{-2}-\mathrm{Al}^{+3}$. However, the peak at $533.8 \mathrm{eV}$ was observed due to the aggregation of $\left(\mathrm{O}_{2}\right)^{2-}$ peroxo species [23]. Thus, the XRD results show not only the peak of $\mathrm{CuAlO}_{2}$ (Fig. 3), but also confirm the presence of $\mathrm{CuAlO}_{2}$ observed on the films by XPS spectra.

The optical transmission spectra of the asdeposited and annealed films at 400, 900, 1000, and $1100{ }^{\circ} \mathrm{C}$ in for $1 \mathrm{~h}$ have shown in Fig. 5. The transmission of the as-deposited and annealed films at $400{ }^{\circ} \mathrm{C}$ rapidly decreases from 90 to $20 \%$ with decreasing the wavelength from 1000 to $200 \mathrm{~nm}$. It might be from the absorption and scattering of the amorphous structure [26]. If the annealing temperature is higher than $900{ }^{\circ} \mathrm{C}$, the transmission slightly decreases with decreasing the wavelength from 1000 to $300 \mathrm{~nm}$. The transmission then rapidly decreases for the wavelengths lower than $300 \mathrm{~nm}$ due to the formation of the $\mathrm{CuAlO}_{2}$ phase on the films [27].

The energy band gap $\left(E_{g}\right)$ values, which can be indicated using the transmission spectra (see Fig. 5),

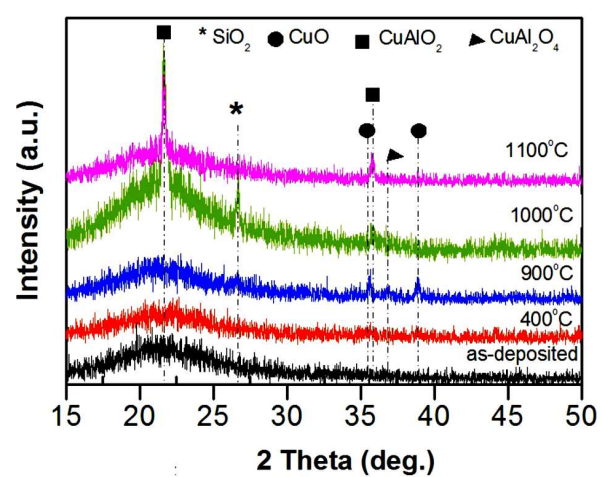

Fig. 3. XRD patterns of the $\mathrm{Cu} / \mathrm{Al}$ films at various annealing temperatures
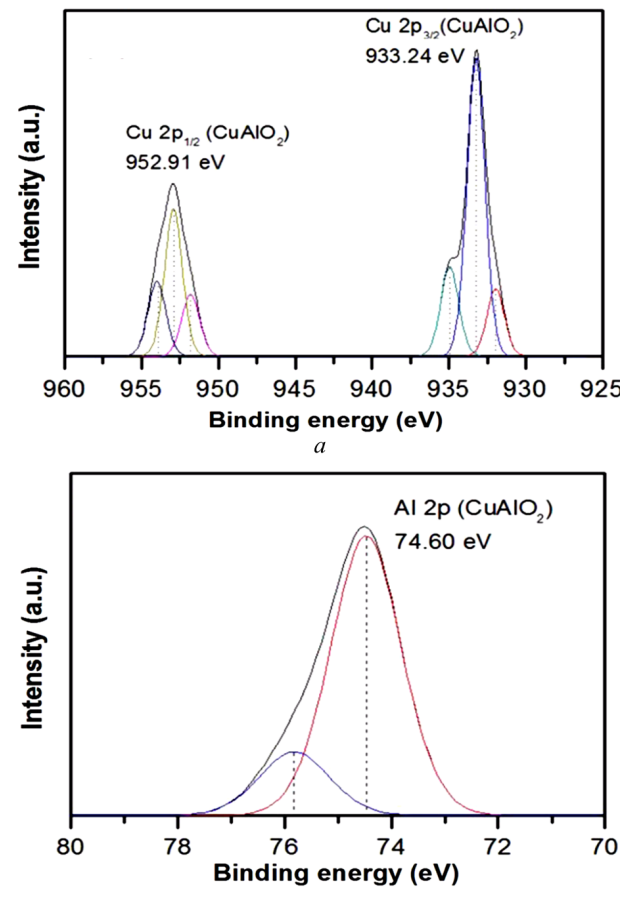

$b$

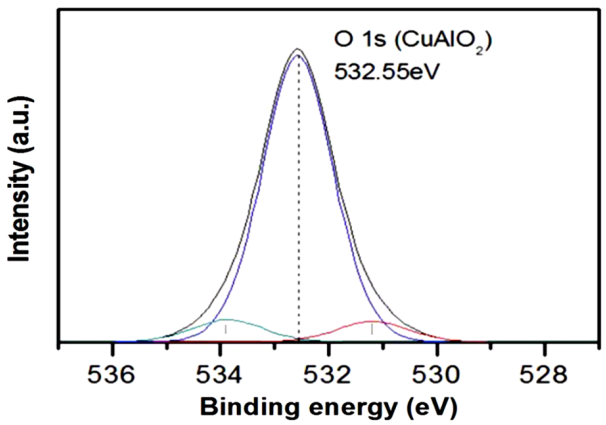

Fig. 4. XPS spectra of $\mathrm{Cu} 2 p(a), \mathrm{Al} 2 p(b)$ and $\mathrm{O} 1 s(c)$; the films were annealed at $1100{ }^{\circ} \mathrm{C}$ for $1 \mathrm{~h}$ 


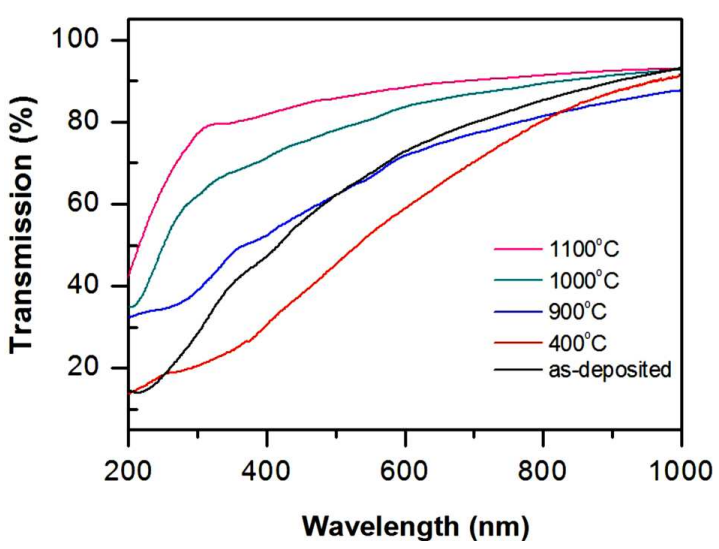

Fig. 5. UV-Vis transmission spectra of the as-deposited and annealed films at various annealing temperatures

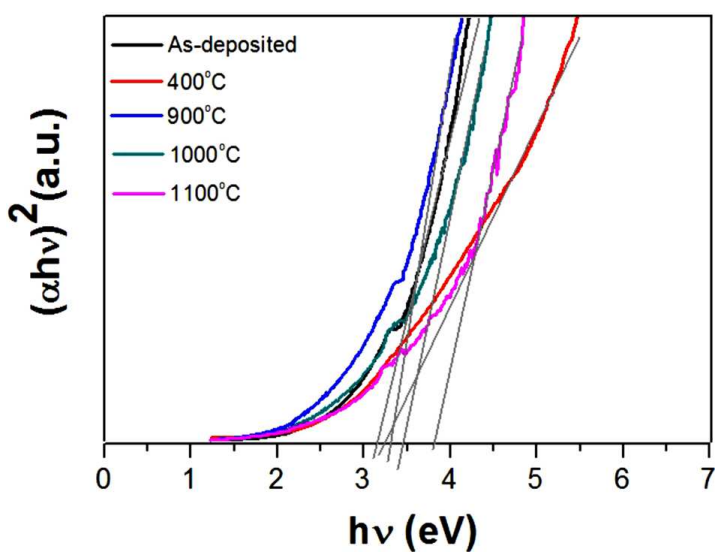

Fig. 6. Plot of $(\alpha h v)^{2}$ versus the photon energy for the determination of the as-deposited and annealed films at various annealing temperatures

are shown in Fig. 6. The Tauc plot is used to generate the optical band gap $\left(E_{g}\right)$ and can be written as follows [28]:

$\alpha h v=A\left(h v-E_{g}\right)^{Z}$,

$\alpha=\frac{1}{t} \ln \left(\frac{1}{T}\right)$.

Here, $\alpha$ is an optical absorption coefficient of the films which can be calculated using relation (2) [29, 37 , $A$ is a constant dependent on the photon energy, $h v$ is the photon energy, and $T$ is the transmittance. The exponential $Z$ is 2 or $\frac{1}{2}$ for the indirect or direct allowed transition. However, the assuming $\alpha$ without the film thickness value $(t)$ was slightly different $[35,36]$. Thus, the optical band gap $\left(E_{g}\right)$ can be determined using a plot of $\left(\ln (1 / T)^{*} h v\right)^{2}$ against the energy $h v$, as shown in Fig. 6. From the figure, the $\left(E_{g}\right)$ of the as-deposited films was $3.2 \mathrm{eV}$, while the annealed films at 400, 900, 1000, and $1100{ }^{\circ} \mathrm{C}$ were $3.3,3.4,3.5$, and $3.8 \mathrm{eV}$ respectively. We note that $E_{g}$ increases with the annealing temperature due to the formation of $\mathrm{CuAlO}_{2}$ at high temperatures [33]. This is because the increasing of the band gap is required to reduce the oxygen deficit [9], which in good agreement with all of the above-mentioned researchers [30-34].

\section{Conclusions}

$\mathrm{Cu} / \mathrm{Al}$ composited films were deposited on the quartz substrate by the single-step sparking method at the atmospheric pressure. The morphology and structural and optical properties of the annealed films at various temperatures are totally different from the as-deposited films. Furthermore, XRD and XPS spectra have confirmed that $\mathrm{CuAlO}_{2}$ in the delafossite phase was formed on the films annealed at high temperatures.

The authors would like to thank the financial support from Thailand Graduate Institute of Science and Technology (TGIST) (SCA-CO-2560-4484-TH, TG-44-10-60-023D), National Science and Technology Development Agency (NSTDA), Center of Advanced Materials for Printed Electronics and Sensors, Materials Science Research Center, the National Research University (NRU) Project under Thailand's office of the Commission on Higher Education (CHE), the Thailand Research Fund (TRF), Center of Excellence in Advanced Materials for Printed Electronics and Sensors (CMU-NECTECH), and the Graduate School Department of Physics and Materials Science, Faculty of Science, Chiang Mai University $G S C M U)$.

1. M. Miclaua, N. Miclaub, R. Banicaa et al. Effect of polymorphism on photovoltaic performance of $\mathrm{CuAlO}_{2}$ delafossite nanomaterials for $p$-type dye-sensitized solar cells application. Materials Today: Proceedings 4, 6975 (2017).

2. S. Pantian, R. Sakdanuphab, A. Sakulkalavek. Enhancing the electrical conductivity and thermoelectric figure of merit of the $p$-type delafossite $\mathrm{CuAlO}_{2}$ by $\mathrm{Ag}_{2} \mathrm{O}$ addition. Current Appl. Phys. 17, 1264-127 (2017).

ISSN 2071-0194. Ukr. J. Phys. 2018. Vol. 63, No. 5 
3. L. Hao, N. Feng, Y. Jinc et al. $\mathrm{CuAlO}_{2}$ thermoelectric compacts by SPS and thermoelectric performance improvement by orientation control. Ceramics International 34, 12154 (2017).

4. K. Vojisavljevic, B. Malic, M. Senna et al. Solid state synthesis of nano-boehmite-derived $\mathrm{CuAlO}_{2}$ powder and processing of the ceramics. J. Europ. Ceramic Society 33, 3231 (2013).

5. T. Suriwong, T. Thongtem, S.Thongtem. $\mathrm{CuAlO}_{2}$ powder dispersed in composite gel electrolyte for application in quasi-solid state dye-sensitized solar cells. Mater. Sci. Semicond. Proc. 39, 348 (2015).

6. A.N. Banerjee, S. Nandy, C.K. Ghosh et al. Fabrication and characterization of all-oxide heterojunction $p$ $\mathrm{CuAlO} \mathrm{Al}_{2+x} / \mathrm{n}-\mathrm{Zn}_{1-x} \mathrm{Al}_{x} \mathrm{O}$ transparent diode for potential application in "invisible electronics". Thin Solid Films $\mathbf{5 1 5}$, 7324 (2007).

7. I.Y.Y. Bu. Optoelectronic properties of novel amorphous $\mathrm{CuAlO}_{2} / \mathrm{ZnO} \mathrm{NWs}$ based heterojunction. Superlatt. Microstruct. 60, 160 (2013).

8. C.-L. Jiang, Q.J. Liu, F.S. Liu et al. Stability and electronic properties of $\mathrm{CuAlO}_{2}$ (1120) surfaces. Current Appl. Phys. 17, 126 (2017)

9. K.R. Murali, M. Balasubramanian. Properties of $\mathrm{CuAlO}_{2}$ thin films deposited by polyacrylamide gel route. Mater. Sci. Semicond. Process. 16, 38 (2013).

10. R.E. Stauber, J.D. Perkins, P.A. Parilla et al. Thin film growth of transparent $p$-type $\mathrm{CuAlO}_{2}$. Electrochem. SolidState Lett. 2, 654 (1999).

11. W. Lan, M. Zhang, G.B. Dong et al. The effect of oxygen on the properties of transparent conducting $\mathrm{Cu}-\mathrm{O}$ thin films deposited by rf magnetron sputtering. Mater. Sci. Engin. $B$ 52, 75 (2009).

12. C.K. Ghosh, S.R. Popuri, T.U. Mahesh et al. Preparation of nanocrystalline $\mathrm{CuAlO}_{2}$ through sol-gel route. J. SolGel Sci. Technol. 139, 155 (2007).

13. K. Tonooka, K. Shimokawa, O. Nishimura. Properties of copper-aluminum oxide films prepared by solution methods. Thin Solid Films 411, 129 (2002).

14. H. Kawazoe, M. Yasukawa, H. Hyodo et al. P-type electrical conduction in transparent thin films of $\mathrm{CuAlO}_{2}$. Nature 389, 939 (1997).

15. S.H. Chiu, J.C.A. Huang. Characterization of $p$-type $\mathrm{CuAlO}_{2}$ thin films grown by chemical solution deposition. Surface \& Coatings Technology 231, 239 (2013).

16. Y. Chuminjak, S. Daothong, A. Kuntarug et al. High-performance electrochemical energy storage electrodes based on nickel oxide-coated nickel foam prepared by sparking method. Electrochimica Acta 238, 298 (2017).

17. T. Ghosh, B. Satpati. Role of oxygen in wetting of copper nanoparticles on silicon surfaces at elevated temperature. Beilstein J. Nanotechnol. 8, 425 (2017).
18. Y. Tian, C. Hang, C. Wang et al. Evolution of $\mathrm{Cu} / \mathrm{Al}$ intermetallic compounds in the copper bump bonds during aging process. Conference on Electronic Packaging Technology, $200 \%$.

19. P. Niggli. Die kristallstruktur einiger oxyde I. Z. Kristallogr., Kristallgeom., Kristallphys., Kristallchem. 57, 253 (1922).

20. J.C. Lambert, W. Eysel. Mineralogical-Petrograph. Institute, Universitat Heidelberg, Germany, ICDD Grant-inAid (1980).

21. W. Gessner. Über die Modifikationen der "Aluminate" $\mathrm{Me}^{\mathrm{I}} \mathrm{AlO}_{2}$ des einwertigen $\mathrm{Ag}, \mathrm{Cu}$ und Tl. Z. Anorg. Allg. Chem. 352, 145 (1967).

22. S. Liu, Z.Wu, Y. Zhang et al. Strong temperaturedependent crystallization, phase transition, optical and electrical characteristics of $p$-type $\mathrm{CuAlO}_{2}$ thin films. Phys. Chem. Chem. Phys. 17, 557 (2015).

23. J. Luo, Y.J. Lin, H.C. Hung et al. Tuning the formation of $p$-type defects by peroxidation of $\mathrm{CuAlO}_{2}$ films. J. Appl. Phys. 114, 033712 (2013).

24. F. Parmigiani, G. Pacchioni, F. Illas et al. Studies of the $\mathrm{Cu}-\mathrm{O}$ bond in cupric oxide by X-ray photoelectron spectroscopy and ab initio electronic structure models. J. Electron Spectrosc. Relat. Phenom. 59, 255 (1992).

25. J.C. Klein, C.P. Li, D.M. Hercules et al. Decomposition of copper compounds in X-ray photoelectron spectrometers. Appl. Spectrosc. 38, 729 (1984).

26. A.S. Reddy, P.S. Reddy, S. Uthanna et al. Characterization of $\mathrm{CuAlO}_{2}$ films prepared by dc reactive magnetron sputtering. J. Mater. Sci.: Mater. Electron. 17,615 (2006).

27. Y.J. Zhang, Z.T. Liu, D.Y. Zang et al. Effect of annealing temperature on the microstructure and optical-electrical properties of $\mathrm{Cu}-\mathrm{O}$ thin films. J. Phys. Chem. Solids 74, 1672 (2013)

28. H. Hiramatsu, W.S. Seo, K. Koumoto. Electrical and optical properties of radiofrequency-sputtered thin films of $(\mathrm{ZnO})_{5} \mathrm{In}_{2} \mathrm{O}_{3}$. Chem. Mater. 10, 3033 (1998).

29. F. Demichelis, G. Kaniadakis, A. Tagliaferro et al. New approach to optical analysis of absorbing thin solid films. Appl. Opt. 26, 1737 (1987).

30. G. Dong, M. Zhang, X. Zhao et al. Influence of working gas pressure on structure and properties of $\mathrm{CuAlO}_{2}$ films. J. Cryst. Growth. 311, 1256 (2009).

31. H. Luo, M. Jain, T.M. McCleskey et al. Optical and structural properties of single phase epitaxial $p$-type transparent oxide thin films. Adv. Mater. 19, 3604 (2007).

32. C. Bouzidi, H. Bouzouita, A. Timoumi et al. Fabrication and characterization of $\mathrm{CuAlO}_{2}$ transparent thin films prepared by spray technique. Mater. Sci. Eng. B 118, 259 (2005).

33. W. Lan, W. L. Cao, M. Zhang et al. Annealing effect on the structural, optical, and electrical properties of $\mathrm{CuAlO}_{2}$ 
films deposited by magnetron sputtering. J. Mater. Sci. 44, 1594 (2009).

34. S.Iping, Z. Lockman, S.D. Hutaglung et al. Formation of $\mathrm{CuAlO}_{2}$ Film by Ultrasonic Spray Pyrolysis. Mater. Sci. Eng. 18, 082022 (2011).

35. Q. Wang, G. Wang, J. Jie et al. Annealing effects on optical properties of $\mathrm{ZnO}$ films fabricated by cathodic electrodepostion. Thin Solid Films 44, 61 (200).

36. T. Kumpika, W. Thongsuwan, P. Singjai. Atomic force microscopy imaging of $\mathrm{ZnO}$ nanodots deposited on quartz by sparking off different tip shapes. Surf. Interface Anal. 39, 58 (2007).

37. J. Tauc. Optical properties and electronic structure of amorphous Ge and Si. Materials Research Bulletin 3, 37 (1968).
А. Пантаван, Т. Кумпіка, В. Сроіла,

Е. Кантарак, В. Тонгпан, П. Пусіхів,

Р. Сорнфанрі, Н. Джумрус, П. Санмуанмун,

А. Туантранонт, П. Синджсан, В. Тонгсуван

МОРФОЛОГІЯ І ФАЗОВЕ

ПЕРЕТВОРЕННЯ ПЛІВОК ОКИСУ МІДІ/АЛЮМІНІЮ

Р е з ю м е

Одностадійним електроіскровим методом при атмосферному тиску отримано окис міді і алюмінію $\mathrm{CuAlO}_{2}$. Тільки що виготовлені плівки відпалені в печі при 400, 900, 1000 i $1100{ }^{\circ} \mathrm{C}$. Результати показали, що морфологія, фазове перетворення і оптичні властивості залежать від температури відпалу. $\mathrm{CuAlO}_{2}$ у фазі делафоссіта утворюється на відпалених плівках за температурою вище $900{ }^{\circ} \mathrm{C}$. Ширина забороненої зони відпалених плівок лінійно зростає від 3,3 до 3,8 еВ із збільшенням температури відпалу від 400 до $1100{ }^{\circ} \mathrm{C}$ завдяки зменшенню дефіциту кисню при високих Received 28.12.17 $\quad$ температурах відпалу. 